\title{
ПОВИШАВАНЕ РАВНИЩЕТО НА МАТЕМАТИЧЕСКИ ЗНАНИЯ НА УЧЕНИЦИТЕ В ПЪРВИ КЛАС ЧРЕЗ РАБОТА СЪС САМОСТОЯТЕЛНО СЪБРАНИ ДАННИ
}

\author{
Д-р Валентина Чилева \\ Югозападен университет „Неофит Рилски“
}

\begin{abstract}
Резюме. През последното десетилетие по отношение на процеса на обучение методици и педагози активно търсят разнообразни средства за мотивиране на познавателната дейност на учениците. Това е свързано с разработване и прилагане в учебната практика на нови подходи и дидактически системи. Настоящата статия разглежда възможността равнището на усвояване на математически знания от учениците в първи клас да се повиши чрез прилагане на похвата „самостоятелно събиране на данни“ в процеса на обучение. Диагностицират се знанията на ученици в първи клас, усвоили учебното съдържание по математика с помощта на самостоятелна изследователска дейност, като се установява ефектьт на тази дейност върху равнището на математическите знания.

Ключови думи: работа с данни; самообучение; повишаване равнището на математическите знания
\end{abstract}

„Проблемът за формиране у учениците на пълноценна учебна дейност не е нов. Редица чуждестранни психолози го анализират от позициите на общопсихологическата теория за дейността и върху основата на концепциите за учебната дейност, разработени в руската психология“ (Stoimenova 2010, 11).

Обучението като процес е свързано с редица дейности от страна на учениците. Те четат, пишат, слушат обяснението на новия учебен материал, отговарят на въпроси, решават задачи. „От учениците се изисква в единство да функционира троичната връзка между знание разбиране и приложение на наученото в училище както по математика, така и по останалите учебни предмети“ (Stamenova $2018,44)$. Обикновено обучителният процес в часовете по математика се структурира на основата на учебното съдържание. Поради спецификата на математическите знания и формирането на свързани с тях умения и навици задачите, включени в учебниците, предоставят на учениците данни, с които те извършват аритметични действия. Акцент се поставя върху автоматизирането на тези 
действия и изменението, което настъпва в процеса на пресмятане, когато данните се променят. Учениците получават наготово всички необходими средства за осъществяване на когнитивни, познавателни действия. За формирането на определените в учебното съдържание математически представи и понятия организирането на учебния процес по този начин е напълно закономерно.

В случаите, когато учениците са се запознали с естествените числа и са усвоили аритметичните действия събиране и изваждане с тях, е целесъобразно в учебния процес да се включат задачи за самостоятелна познавателна дейност и похвати за самостоятелно придобиване на знания.

С оглед на идеята за развиващото обучение през последните години въпросът за начина на учене на учениците става все по-актуален. Учебно-възпитателната дейност вече не се свежда само до натрупване на определени научни знания, но и до развиване на умствените операции, необходими за формиране на житейски понятия.

Въпросът за учебния процес и неговата структурна организираност е разработен подробно от Д. Денев (1977). Авторьт предлага модел на учебния процес, с който дава насоки за управлението на самия процес, придобиването на знания и формиране на умения (фиг. 1).

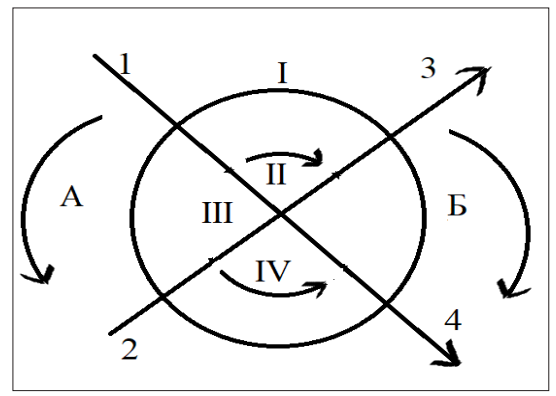

Фигура 1. Модел на учебния процес на Д. Денев ${ }^{1)}$

Структурата на модела е изоморфна и обхваща три основни момента:

- получаване на информация $(1,2)$;

- преобразуване на получената информация (I, II, III, IV);

- дейност $(3,4)$.

В представения модел информацията, с която учениците боравят, се получава от два източника: обучение (1), осъществяващо се в училище, при което учебното съдържание е основен източник на информация, и самообучение (2), което може да се осъществи извън рамките на учебния час или в него, но при специфични дидактични условия. Модельт на Д. Денев отбелязва изключително важната роля на самообучението като източник на информация наред с обучението. 
Моделът на учебния процес съдържа също и два вида дейности: учене (3) и творческа дейност (4). Усвояването на математически знания и формирането на понятия в учебния процес е пряко свързано с преработването на информация. Този процес е резултат от четири връзки и зависимости, отразени в изоморфния модел: между обучението и ученето (I), между обучението и творческата дейност (II), между самообучението и ученето (III), между самообучението и творческата дейност (IV).

В структурния модел са изобразени и две външни страни на учебния процес. Преминаване от обучение към самообучение $(\mathrm{A})$ и преминаване от учене към творческа дейност (Б).

В общи линии, представеният модел очертава двете основни структури, които изграждат учебния процес: обучителна и самообучителна дейност. Обучителната дейност се ръководи от учителя. Тя включва учебното съдържание, представено в учебниците по математика, и следва конкретни учебни цели, заложени в урочните единици. Самообучителната дейност също е подчинена на конкретни учебни цели, но тя предоставя по-голяма свобода на организиране и реализиране. Както вече бе отбелязано, самообучението може да се осъществи извън рамките на учебния час и със средства, позволяващи изпълнението на учебни дейности с високо творческо съдържание. Самостоятелното събиране и представяне на данни е част от творческата математическа дейност. То позволява на учениците да организират, анализират и репрезентират данни по-начин, различен от представения им в учебниците по математика. Творческият поглед, който самостоятелното събиране на данни изисква от учениците, поражда активен и съзнателен самообучителен процес.

За съвременното развиващо обучение от особено значение е осъществяването на тясна и неразривна връзка между самообучение и учене. Ако се приеме, че образователната дейност е насочена предимно към запознаване на учениците с материалните и духовните достижения на науката и техниката, то самообучението е дейност, която осигурява допълнително познавателно обезпечаване в сравнение с получаваните знания от учебното съдържание. Самообучението е тясно свързано с познавателните интереси, с появата на нови мотиви за овладяване на знания и задоволяване на научна любознателност. Благодарение на самообучението научните познания и прийомите за умствена дейност на учениците се разширяват и задълбочават.

Една от основните цели на обучението по математика в началните класове е да осигури на учениците знания и умения за количествено определяне на обектите и явленията от действителността. За осъществяването на тази цел е необходимо учениците непрекъснато да оперират с данни от заобикалящата ги среда. Работата с данни се осъществява с изчислителна насоченост, като се пресмята стойността или общата съвкупност на посочени обекти и числови стойности. 
В началните класове учениците работят предимно с данни, които им се предоставят от учителя. Процесът на работа с данни, които са предоставени наготово, е различен от този, при който учениците сами събират необходимите им данни. В първия случай се работи на по-ниско равнище на умствена дейност, докато при втория случай равнището на умствена дейност е високо и включва съвкупност от по-голям брой когнитивни процеси.

Процесьт на работа с данни, които са предварително осигурени на учениците преминава през няколко етапа (фиг. 2).

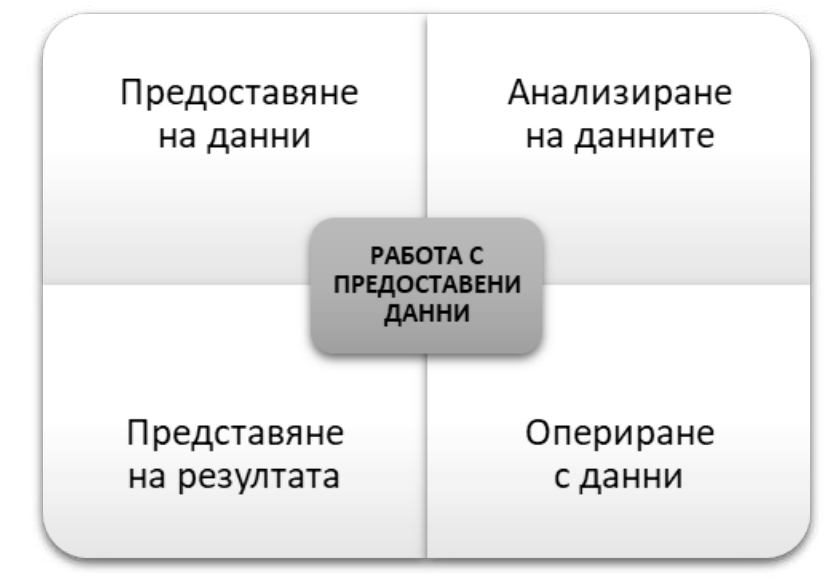

Фигура 2. Процес на работа с предоставени данни

Нека на учениците бъде предоставена следната задача:

В трети клас на ОУ „Христо Ботев“ 5 ученици са родени през месец май, 3 през месеи март, 2 през месеи юни, 1 през август ,4 ученици през ноември и 6 през януари. С колко на брой учениците, родени през пролетните месеци, са по-малко на брой от учениците, родени през зимните месеци?

Процесът на работа с данни започва от първия етаn, при който данните са предоставени в готов вид под формата на текстова задача. Тези данни отразяват едновременно числовата стойност на обектите и категориалния характер на данните.

Bmopuяm eman е свързан с анализирането на предоставените данни. Чрез внимателно прочитане на задачата и разглеждане на данните учениците осъществяват анализ на предметната област, към която се отнасят обектите. Определя се кои точно обекти характеризират тази област и каква зависимост съществува между обектите и числовите данни.

След възприемането и внимателното анализиране на данните процесът на работа с данни преминава към опериране със самите данни. През този етап 
се пристьпва към осъществяване на определени аритметични действия с числовите данни. Съставя се числов израз и се извеждат релационни отношения.

Последния етап от процеса на работа с данни включва представяне на резултата. Обикновено, когато данните са предоставени на учениците от учителя, резултатьт от дейността работа с данни се представя означено с помощта на числов израз или изчислено под формата на краен резултат от изведената аритметична операция.

Основната цел на работата с предоставени данни е учениците да усъвършенстват своите изчислителни умения и да усвоят някои математически особености при работа с различни по вид математически задачи. Тази цел удовлетворява малък процент от знанията и уменията, заложени в учебните програми по математика в I - IV клас. Необходимо е на учениците да се предостави възможност сами да събират и анализират данни, с което да се инициират процеси на осъзнаване на математическите зависимости, които съществуват между обектите в заобикалящото ни ежедневие, и да се усвоят умствени похвати за решаване на математически задачи.

В учебно-възпитателния процес могат да се използват задачи, които изискват от учениците сами да набавят необходимите им данни. Такъв тип задачи дават възможност за осъществяване на елементарна изследователска дейност за реализиране на самообучителен процес. В тези случаи процесът на работа с данни преминава през различни етапи, сравнен с етапите на процеса, при който данните са предоставени в готов вид (фиг. 3 ).

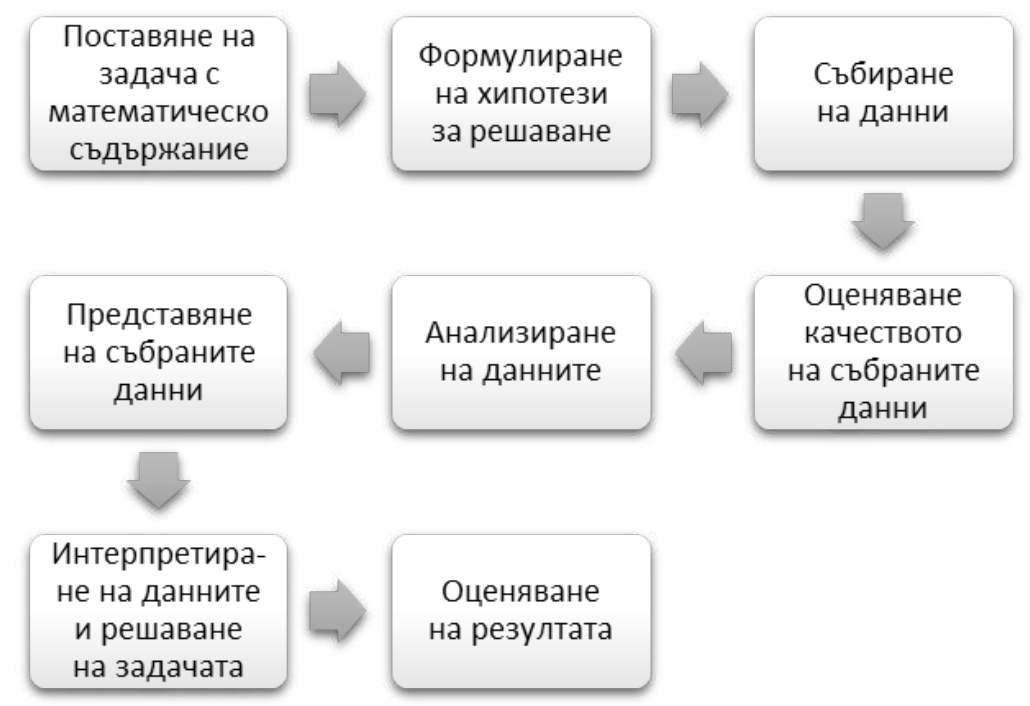

Фигура 3. Процес на работа със самостоятелно събрани данни 
Процесът на работа с данни, които учениците трябва самостоятелно да съберат, започва с поставянето на въпрос към учениците или въвеждането им в определена ситуация, което представлява първият етаn от процеса на работа със самостоятелно събрани данни. Препоръчително е поставеният выпрос или създадената ситуация да бъдат свързани с интересни за тях данни. Например учителят иска от учениците да решат задача, свързана с най-предпочитания вид обувки в клас, като се определи броят на всеки вид обувки и се диференцира каква част от общия брой се отнася за момичетата и каква част - за момчетата в класа. Учениците оглеждат обувките на своите съученици и формулират хипотези, като изказват предположения, основани на техните наблюдения. По този начин те реализират втория етап от процеса на работа със самостоятелно събрани данни, а именно формулиране на хипотези за решаване на поставената задача. След етапа на формулиране на хипотези се поставя началото на процеса на работа с данни, като се реализира третияm еman, свързан със събирането на данните.

Събирането на данни не е произволен и хаотичен процес, а абсолютно целенасочен и ориентиран от предметната област, която учителят задава. Поставянето на въпрос или въвеждането на ситуация е необходимо да се осъществи по начин, който достатъчно ясно и категорично да посочи на учениците какви данни точно е необходимо да намерят.

В конкретната ситуация с обувките събирането на данни може да се осъществи, като всички ученици се подредят в редица така, че ясно да се откроят видовете обувки, които ще се категоризират. Правят се предложения за типа категории обувки като дамски и мъжки, официални и ежедневни, едноцветни и многоцветни и т.н.

Четвъртият етап от процеса на работа с данни, които учениците сами осигуряват, е оценяване качеството на събраните данни. Процесът на събиране на данни неизменно е свързан с необходимостта те да бъдат оценени. Оценяването на данните е насочено към това да се определи кои от събраните данни са подходящи за поставената ситуация или въпрос. През този етап се осъществява диференцирането на необходимите от излишните данни.

В конкретния случай от всички дадени предложения за категоризиране на данните се избират тези, които да обхванат вида обувки на всяко дете в класа. Основната идея на този етап е учениците да достигнат до извода, че различните категории ще включват различно количество данни, защото не всички деца в класа носят еднакви обувки.

След оценяването на данните се преминава към петия етап от процеса на работа с данни, който се отнася до анализиране на събраните данни. Анализът на данните е насочен към определяне на действащите обекти, техните числови стойности и релационни отношения. На този етап учениците установяват количествените характеристики на всяка категория обувки. Съответно кои са най-много и кои -най-малко. 
Шестият eman от процеса на работа с данни е посветен на представянето на събраните данни. В случаите, когато учениците оперират с предоставени наготово данни, те ги представят с помощта на числов израз и изчислен отговор. При представяне на данни, които учениците сами са събрали, се използва илюстративно репрезентиране под формата на графики и таблици.

След като се определят категориите и се анализират количествените стойности на данните, те могат да бъдат представени с помощта на таблици. За да бъде улеснен процесът на графично представяне, на учениците се предоставя лист с празна таблица. Срещу всяка колона в таблицата се поставя знак на категорията обувки, които учениците са избрали. Най-често този знак е картинно изображение на обекта. За всяка от категориите обувки се избира цвят. Учениците оцветяват толкова квадратчета от съответната категория, колкото деца носят посочените обувки (фиг. 4).

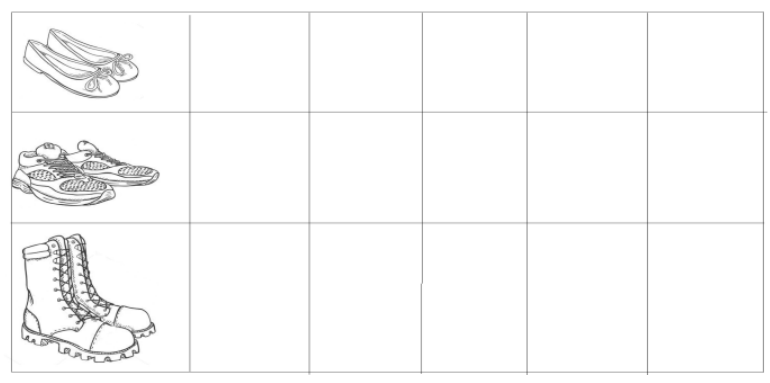

Фигура 4. Таблично представяне на данни

Следващият, седми eman от работата със самостоятелно събрани данни е интерпретиране на тези данни. Интерпретирането на данни позволява да се даде отговор на поставената задача, без да се използват изчислителни изрази и аритметични действия. Отговорите се базират на репрезентативно представените твърдения. Достигането до търсения отговор се основава на наблюдения и умозаключения, а не на математически изчисления.

След като учениците съставят диаграмното изображение на данните, е необходимо тяхното внимание да се съсредоточи върху броя категории и количеството данни във всяка категория, т.е. да погледнат отвъд табличното представяне. Това съсредоточаване става, като учителят насьрчи учениците да отговорят на въпроси като следните:

- Всички категории ли съдържат еднакъв брой обувки?

- Сравнете в коя категория обувките са най-малко. А най-много?

Отговорът на тези косвени въпроси ще позволи на учениците да отговорят на първоначалния въпрос „Кой вид обувки са най-предпочитани от нашия клас?“. 
Съставянето на диаграма и отговарянето на първоначално зададения въпрос не слага край на работата на учениците. Работата продължава, като се изиска всеки ученик да определи в коя категория на обувки се намира, което представлява и последния етаn, в който данните се оценяват и се правят допълнителни изводи и обобщения. Ако диаграмното изображение има само единица количество в дадена категория, може да се определи кой е притежателят на този единствен чифт обувки.

Установяването на отделна, единствена единица данни е важен процес, който ще позволи на учениците да възприемат отделните елементи, от които е съставена дадена система, като единно цяло. На учениците могат да се зададат и допълнителни въпроси: клас?

- Можем ли да очакваме различни резултати, ако събираме данни от друг

- Свързан ли е видът обувки с възрастта?

- Как би изглеждала диаграмата, ако събирате данни от училище в Хавай?

C помощта на такъв тип въпроси учениците се учат да намират причините за разликите, съществуващи в разпределението на данните.

С цел да се установи какво влияние оказва процесът на самостоятелно събиране на данни върху усвояването на математически знания на учениците в първи клас, се проведе дидактически експеримент, организиран в три етапа. Експериментът се осъществи в СУ „Арсени Костенцев“ - Благоевград, през календарната 2019/2020 година. Поради неграмотността на учениците в първи клас и липсата на основни математически знания в началото на учебната година дидактическият експеримент се проведе от месец февруари до месец май. Избрани са два първи класа, като единият се включва в качеството си на контролен клас (22 ученици), а другият - на експериментален (20 ученици).

На първия етап (констатиращ) се установява равнището на математически знания, с които децата постьпват в училище. За тази цел им е предоставена самостоятелна работа (приложение 1) с характер на входяща диагностика.

Оценяването на отделните показатели се осъществява с помощта на тристепенна скала по равнища. Първо равнище от скалата - „не знае“, се отнася за задачи, които са решени напълно грешно или ученикът е отказал да реши. Второ равнище - „изпитва колебание“, се отнася за случаите, в които ученикът е използвал правилно алгоритъма за изчисление, но не е пресметнал вярно или не е успял да реши правилно всички зададени подусловия. Трето равнище - „знае“, е показател, че ученикът е приложил правилния алгоритъм за решаване, пресметнал е вярно и е решил всички предоставени подусловия. В зависимост от това как е решена всяка задача, тя се оценява спрямо равнището на прилагане на знанията. Ако задачата е решена на първо равнище, тя се оценява с 1 точка, на второ - с 2, и съответно на трето равнище - с 3 точки. 
След оценяването на всяка задача със съответното равнище се намира средната аритметична величина за отделните типове задачи и за отделните равнища. Използва се формулата за средна аритметична величина за изчисляване резултатите на всеки отделен клас:

$$
\bar{X}=\frac{\sum_{i=1}^{N} X_{i}}{N}
$$

където $x$ е средната аритметична величина; $i$ са значенията на $N$ - признака, по които се прави осредняването при $\mathrm{i}=1,2,3, \ldots, \mathrm{N} ; \mathrm{N}$ е обемът на изучаваната съвкупност, включващ единиците, попадащи в нея.

Резултатите, получени в процеса на обработване на дидактическите тестове за контролния клас, са посочени в таблица (табл. 1).

Таблица 1. Равнище на усвоеност на математическите знания при КК

\begin{tabular}{|l|c|c|c|c|c|c|c|}
\hline $\begin{array}{r}\text { Тип } \\
\text { задача }\end{array}$ & $\begin{array}{c}\text { Установяване } \\
\text { на } \\
\text { съответствие }\end{array}$ & Броене & $\begin{array}{c}\text { Установяване } \\
\text { на релационни } \\
\text { отношения }\end{array}$ & $\begin{array}{c}\text { Писане } \\
\text { на числа }\end{array}$ & $\begin{array}{c}\text { Разпознаване } \\
\text { на } \\
\text { геометрични } \\
\text { фигури }\end{array}$ & $\begin{array}{c}\text { Прибавяне } \\
\text { на обекти }\end{array}$ & $\bar{X}$ \\
\hline Високо & 54,54 & 50,00 & 40,90 & 59,09 & 63,63 & 54,54 & 53,78 \\
\hline Средно & 45,46 & 50,00 & 59,10 & 41,91 & 36,37 & 45,46 & 46,22 \\
\hline Ниско & 0,00 & 0,00 & 0,00 & 0,00 & 0,00 & 0,00 & 0,00 \\
\hline
\end{tabular}

След като данните от контролния клас се обработят, се пристьпва към обработване на данните от самостоятелните работи на експерименталния клас.

Резултатите, получени в процеса на обработване на дидактическите тестове за експерименталния клас, са посочени в таблица (табл. 2).

Таблица 2. Равнище на усвоеност на математическите знания при ЕК

\begin{tabular}{|l|c|c|c|c|c|c|c|}
\hline $\begin{array}{r}\text { Тип } \\
\text { задача }\end{array}$ & $\begin{array}{c}\text { Установяване } \\
\text { на } \\
\text { съответствие }\end{array}$ & Броене & $\begin{array}{c}\text { Установяване } \\
\text { на релационни } \\
\text { отношения }\end{array}$ & $\begin{array}{c}\text { Рисане } \\
\text { на числа }\end{array}$ & $\begin{array}{c}\text { Разознаване } \\
\text { на } \\
\text { геометрични } \\
\text { фигури }\end{array}$ & $\begin{array}{c}\text { Прибавяне } \\
\text { на обекти }\end{array}$ & $\bar{X}$ \\
\hline Високо & 55,64 & 51,45 & 43,90 & 60,00 & 65,54 & 54,54 & 55,18 \\
\hline Средно & 44,36 & 48,55 & 56,10 & 40,00 & 34,46 & 45,46 & 44,82 \\
\hline Ниско & 0,00 & 0,00 & 0,00 & 0,00 & 0,00 & 0,00 & 0,00 \\
\hline
\end{tabular}


След анализиране на получените данни е установено, че равнището на математически знания, с които учениците от експерименталния и контролния клас постьпват в училище, е близко. Това дава основание да се смята, че постигнатите в края на експерименталното обучение резултати ще притежават висока степен на достоверност.

Вторият етап от дидактическия експеримент е осъществен с учениците от експерименталния клас. По време на този етап учебно-възпитателната дейност е проведен с помощта на допълнителни към учебното съдържание задачи, които изискваха от учениците да работят с числови данни, събрани от тях самите. Модели на примерни задачи за самостоятелно събиране на данни са представени в приложение 2 .

Последният етап от дидактическия експеримент е с контролен характер и се реализира в края на дидактическия експеримент. С помощта на самостоятелна работа (приложение 3), която притежава характеристиките на изходяща диагностика, се установи равнището на математически знания, които учениците са усвоили по време на организираното специфично обучение.

Резултатите, получени в процеса на обработване на дидактическите тестове за контролния клас, са посочени в таблица (табл. 3).

Таблица 3. Равнище на усвоеност на математическите знания при КК

\begin{tabular}{|l|c|c|c|c|c|c|c|}
\hline $\begin{array}{r}\text { Тип } \\
\text { задача }\end{array}$ & $\begin{array}{c}\text { Установяване } \\
\text { на реда на } \\
\text { естествените } \\
\text { числа }\end{array}$ & $\begin{array}{c}\text { Събиране } \\
\text { и } \\
\text { изваждане }\end{array}$ & $\begin{array}{c}\text { Установяване } \\
\text { на } \\
\text { релационни } \\
\text { отношения }\end{array}$ & $\begin{array}{c}\text { Решаване } \\
\text { на } \\
\text { текстови } \\
\text { задачи }\end{array}$ & $\begin{array}{c}\text { Геометрични } \\
\text { знания }\end{array}$ & $\begin{array}{c}\text { Мерки и } \\
\text { именувани } \\
\text { числа }\end{array}$ & $\bar{X}$ \\
\hline Високо & 68,73 & 68,36 & 49,65 & 72,48 & 75,45 & 69,56 & 67,37 \\
\hline Средно & 31,27 & 31,64 & 50,35 & 27,52 & 24,55 & 30,44 & 32,63 \\
\hline Ниско & 0,00 & 0,00 & 0,00 & 0,00 & 0,00 & 0,00 & 0,00 \\
\hline
\end{tabular}

Резултатите, получени в процеса на обработване на дидактическите тестове за експерименталния клас, са посочени в таблица (табл. 4).

Таблица 4. Равнище на усвоеност на математическите знания при ЕК

\begin{tabular}{|l|c|c|c|c|c|c|c|}
\hline $\begin{array}{r}\text { Тип } \\
\text { задача }\end{array}$ & $\begin{array}{c}\text { Установяване } \\
\text { на реда на } \\
\text { естествените } \\
\text { числа }\end{array}$ & $\begin{array}{c}\text { Събиране } \\
\text { и } \\
\text { изваждане }\end{array}$ & $\begin{array}{c}\text { Установяване } \\
\text { на } \\
\text { релационни } \\
\text { отношения }\end{array}$ & $\begin{array}{c}\text { Решаване } \\
\text { на } \\
\text { текстови } \\
\text { задачи }\end{array}$ & $\begin{array}{c}\text { Геометрични } \\
\text { знания }\end{array}$ & $\begin{array}{c}\text { Мерки и } \\
\text { именувани } \\
\text { числа }\end{array}$ & $\bar{X}$ \\
\hline Високо & 75,54 & 83,63 & 72,68 & 85,48 & 88,35 & 78,76 & 80,74 \\
\hline Средно & 24,46 & 16,37 & 27,32 & 14,52 & 11,65 & 21,24 & 19,26 \\
\hline Ниско & 0,00 & 0,00 & 0,00 & 0,00 & 0,00 & 0,00 & 0,00 \\
\hline
\end{tabular}


От изведените данни в таблиците се вижда, че броят ученици, усвоили математическите знания за определяне на естествения ред на числата на високо равнище в ЕК $(75,54 \%)$, е по-висок от броя ученици в КК $(68,73 \%)$. Грешките, които учениците допускат при решаването на задачи от такъв тип, са свързани не толкова с наличие на пропуски в знанията, а по-скоро на подценяване същността на самата задача. По отношение на прилагането на знания за аритметичните действия събиране и изваждане при учениците от експерименталния клас се наблюдават по-малко грешки и по-малък брой ученици, които показват средно равнище на усвоеност $(16,37 \%)$, в сравнение с контролния клас $(31,64 \%)$. Самостоятелното събиране на данни и тяхното обработване позволява на учениците от ЕК да извършват изчисления в ситуации, с които не са се сблъсквали в учебната среда. Тази възможност води до обобщаване и систематизиране на знанията за аритметичните действия и прилагането на тези знания на по-високо равнище при задачи за пресмятане.

Най-големи затруднения учениците от контролния клас изпитват при вярното установяване на релационни отношения. Това се дължи на комплексността на сравнението, което изисква сравняване на сбор с число или сравняване на разлика с число. При учениците в експерименталния клас тези затруднения до голяма степен са преодолени, защото в своята самостоятелна дейност за събиране на данни те непрекъснато са в състояние на определяне и сравняване на категориите данни.

Решаването на текстови задачи от учениците в първи клас представлява сложен за тях процес. Това се дължи на факта, че формирането на понятието текстова задача и усвояването на знания за структурата и особеностите на този тип задачи започва в първи клас. Самият процес на решаване изисква да се открои условието с посочените в него обекти, числовите данните и съществуващата между тях зависимост, както и да се осмисли поставеният въпрос. Всички тези фактори оказват влияние върху правилното съставяне и пресмятане на числовия израз, който ще посочи отговора на поставения въпрос. Данните, получени при обработката на резултатите относно равнището на решаване на текстови задачи в двата класа, са закономерни. Броят ученици от ЕК $(85,48 \%)$, които решават текстови задачи на високо равнище, е по-голям от същия брой ученици при КК (72,48\%). Самостоятелното събиране на данни в условие на конкретна ситуационна задача налага аритметично обработване на тези данни. Учениците в експерименталния клас, събирайки данни, ги подлагат на изчислително въздействие, те събират или изваждат числовите стойности за отделните категории, като по този начин затвърдяват и систематизират знанията си за изучените от тях аритметични действия. По отношение на последните два показателя - геометрични знания и работа с мерки и именувани числа. Броят ученици, които са решили задачите на високо равнище в ЕК (88,35\% и съответно $78,76 \%$ ) е по-голям от броя ученици в КК (75,47\% и съответно 69,56\%). Добро впечатление и за двата класа прави отсъст- 
вието на задачи, които са решени на ниско равнище. Въпреки затрудненията, които са изпитали, учениците са положили старание да решат всички задачи. Този факт показва високо ниво на мотивираност за осъществяване на учебна дейност при първокласниците от изследваните класове.

При обработка на резултатите, получени за всяко равнище, средните величини са закономерни. Данните са поместени в диаграма (фиг. 5).

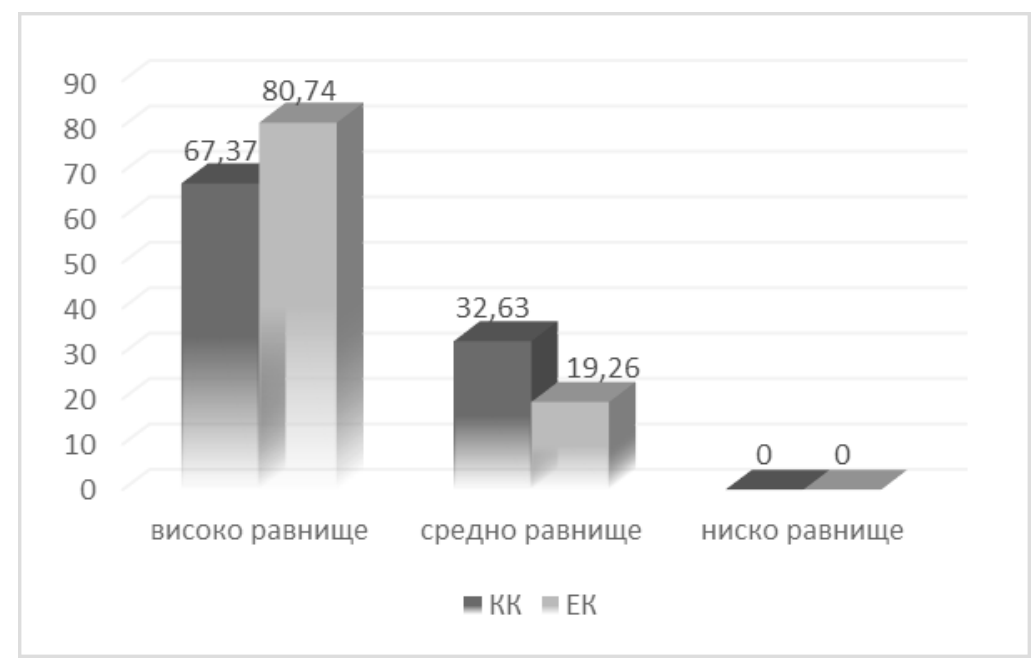

Фигура 5. Равнища на прилагане на математически знания

От изведената диаграма ясно се очертава положителното въздействие върху познавателната дейност на учениците от работата със самостоятелно събрани данни. Учениците от експерименталния клас, при които бе проведена целенасочена педагогическа дейност за самостоятелно събиране и обработване на данни, показват по-голямо процентно разпределение $(80,74$ \%) на високо равнище на прилагане на математическите знания в сравнение с контролния клас, при който процентът е по-нисък (67,37\%). Самостоятелната дейност по събиране и обработване на данни повишава активността и съзнателността на прилагане на математическите знания. Това се отразява в средното равнище на прилагане на математически знания, при което допусканите грешки често са резултат от прибързаното решаване на задачите. Самостоятелното събиране на данни развива умения за прецизно изчисляване, от тук и резултатите, касаещи средното равнище на прилагане на математически знания за експерименталния клас $(19,26 \%)$, е по-ниско в сравнение с контролния (32,63\%). При анализиране на получените данни впечатление прави, че няма ученици от контролния и експерименталния клас, които да показват ниско равнище на прилагане на математическите 
знания. От тук може да се направи заключението, че похватът „самостоятелно събиране на данни“ оказва положително въздействие при повишаване равнището на прилагане на математически знания в прогресия от средно към високо.

Началният училищен курс по математика създава необходимата основа за по-нататъшното обучение на учениците и съставлява органическа част от цялостния училищен процес. Познавателната дейност на учениците в обучението по математика в първи клас се характеризира с редица специфични особености. Именно тези особености, съчетани с индивидуалните различия на самите ученици, са причината математическите знания да се овладяват на различни равнища при всеки един от тях.

Осигуряването на възможност за работа с данни, които учениците сами са събрали, повишава равнището на усвояване на математическите знания в първи клас. Учебното съдържание се възприема по-съзнателно, а самите ученици се превръщат в активни участници на учебния процес. Математическите знания, с които учениците се запознават, придобиват житейска, практическа насоченост, което ги преврьща в желани, а не задължителни за усвояване. Като цяло, прилагането на похвата „самостоятелно събиране на данни“ подпомага обучението по математика на учениците в първи клас както в учебно-възпитателния, така и в мотивационния аспект.

\section{Приложение 1}

\section{САМОСТОЯТЕЛНА РАБОТА}

Входяща диагностика

Задача 1. Нарисувай толкова крьгчета, колкото са таралежите.
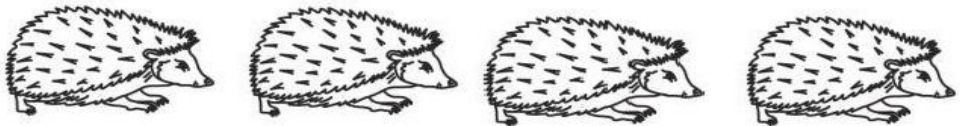

Задача 2. Преброй колко са ябълките и запиши техния брой в квадратчето.
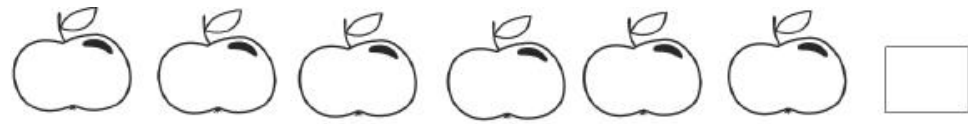

Задача 3. Напиши пропуснатите числа.

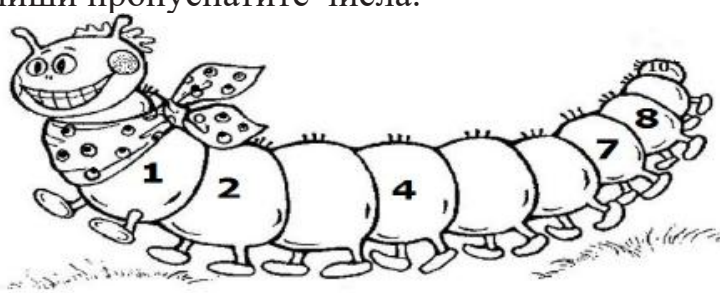


Задача 4. Огради групата, в която листата са повече.
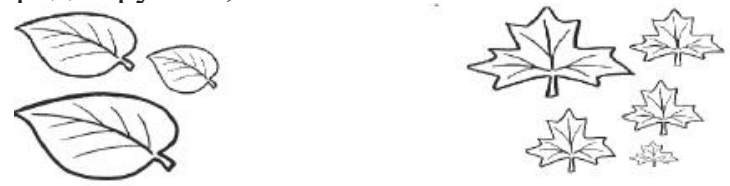

Задача 5. Кои геометрични фигури разпознаваш. Оцвети кръговете.
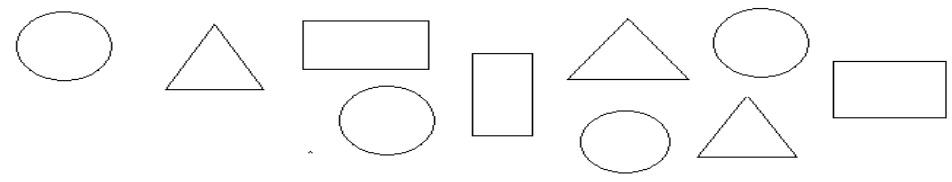

Задача 6. Дорисувай колкото ягоди са необходими, така че техният брой да стане 5.
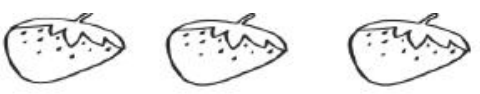

\section{Приложение 2}

\section{ЗАДАЧИ ЗА САМОСТОЯТЕЛНО СЬБИРАНЕ И ОБРАБОТВАНЕ НА ДАННИ}

\begin{tabular}{|l|l|}
\hline \multicolumn{1}{|c|}{ Задача } & \multicolumn{1}{|c|}{ Дидактическа цел } \\
\hline $\begin{array}{l}\text { 1. „Любимо животно от зоологическата градина“ } \\
\text { На учебната дъска се поставя табло } \\
\text { с изобразени на него животни. }\end{array}$ & $\begin{array}{l}\text { - Да се затвърдят зна- } \\
\text { нията на учениците за } \\
\text { количествената опреде- } \\
\text { леност на числата. } \\
\text { - Да се затвърдят зна- } \\
\text { нията на учениците за } \\
\text { релационните отноше- } \\
\text { ния. } \\
\text { - Да се затвърдят } \\
\text { знанията на ученици- } \\
\text { те за извършване на } \\
\text { аритметичните действия } \\
\text { събиране и изваждане. }\end{array}$ \\
$\begin{array}{l}\text { Провежда се беседа за това кои видове животни са } \\
\text { изобразени и къде можем да ги срещнем. След това } \\
\text { всеки ученик от класа излиза на дъската и поставя точка } \\
\text { под животно, което му е любимо. Накрая с помощта на } \\
\text { насочващи въпроси от учителя се определя коя категория } \\
\text { животни е най-предпочитана и съответно коя - най-не- } \\
\text { предпочитана. Установява се и количествената разлика } \\
\text { между отделните категории, те. с колко дадена категория } \\
\text { е повече или по-малко от друга. }\end{array}$ \\
\hline \multicolumn{2}{|l|}{} \\
\hline
\end{tabular}




\section{2. „Какво е времето?“}

За всеки ученик от класа се изработва специална карта, върху която ще нанася събраните от него данни. Самата карта съдържа таблица с изобразени знаци, отразяващи различни климатични условия. Целта е да се проследи какви са били климатичните условия в рамките на една седмица.

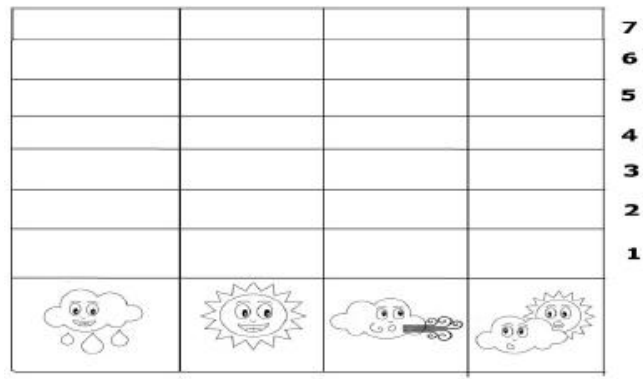

Всеки ученик попълва самостоятелно своята карта. В края на седмицата събраните данни се обсъждат. Установява се броят дни за всяка категория и тяхното релационно отношение. Обсъжда се и самият начин на събиране на данни, доколко той е обективен. Дали през даден ден един ученик е определил времето като облачно, а друг като дъждовно.

\section{3. „Любими плодове в семейството“}

За всеки ученик от класа се изработва специална карта, върху която ще нанася събраните от него данни. Самата карта съдържа таблица с изобразени плодове.

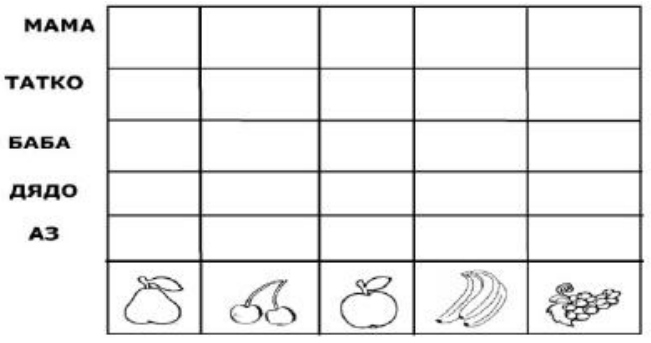

Всеки самостоятелно прави елементарно проучване на любимите плодове на членовете от своето семейство (картите се коригират в зависимост от самите членове на семейството и техния брой). Събраните данни се обсъждат и сравняват. Поставя се допълнително условие с помощта на събраните от него данни всеки ученик да състави текстова задача и да я реши.
- Да се затвърдят знанията на учениците за количествената определеност на числата.

- Да се затвърдят знанията на учениците за релационните отношения.

- Да се затвърдят знанията на учениците за извършване на аритметичните действия събиране и изваждане. - Пропедевтично въвеждане на мерна единица за време „седмица“.

- Да се затвърдят знанията на учениците за релационните отношения.

- Да се затвърдят знанията на учениците за извършване на аритметичните действия събиране и изваждане. - Да се затвърдят знанията на учениците за съставяне и решаване на текстови задачи. 
4. „Кой се е подготвил за часа?“

На класната дъска се поставя табло с две скали от данни: брой ученици и предмети за работа.

Целта е да се провери колко ученици носят необходимите им пособия за конструктивна работа.
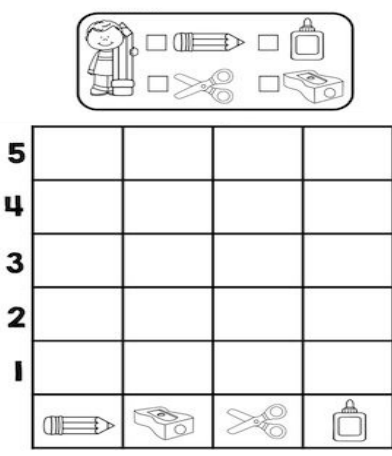

- Да се затвърдят знанията на учениците за релационните отношения.

- Да се затвърдят знанията на учениците за извършване на аритметичните действия събиране и изваждане.

\section{Приложение 3}

\section{САМОСТОЯТЕЛНА РАБОТА}

Изходяща диагностика

\section{1. Попьлни.}

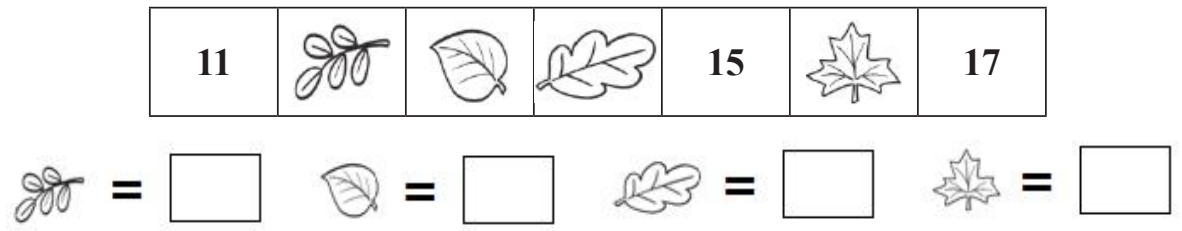

\section{2. Попълни.}

\begin{tabular}{|l|l|l|l|l|}
\hline Събираемо & 5 & 4 & & 30 \\
\hline Събираемо & 10 & & 7 & 60 \\
\hline Сбор & & 12 & 20 & \\
\hline
\end{tabular}

\begin{tabular}{|l|l|l|l|l|}
\hline Умаляемо & 12 & 20 & & 80 \\
\hline Умалител & 7 & & 6 & 60 \\
\hline Разлика & & 9 & 5 & \\
\hline
\end{tabular}

\section{3. Поправи, ако е необходимо.}

$12+3>1820=10+1016-4<12 \quad 15-1>11 \quad 17+2=20$ 
4. В кошница има 7 кг ябълки, а в касетка - с 5 кг повече.

Колко килограма ябълки има в касетката? Огради вярното представяне на броя ябълки в касетката.

Решение:

Отговор:
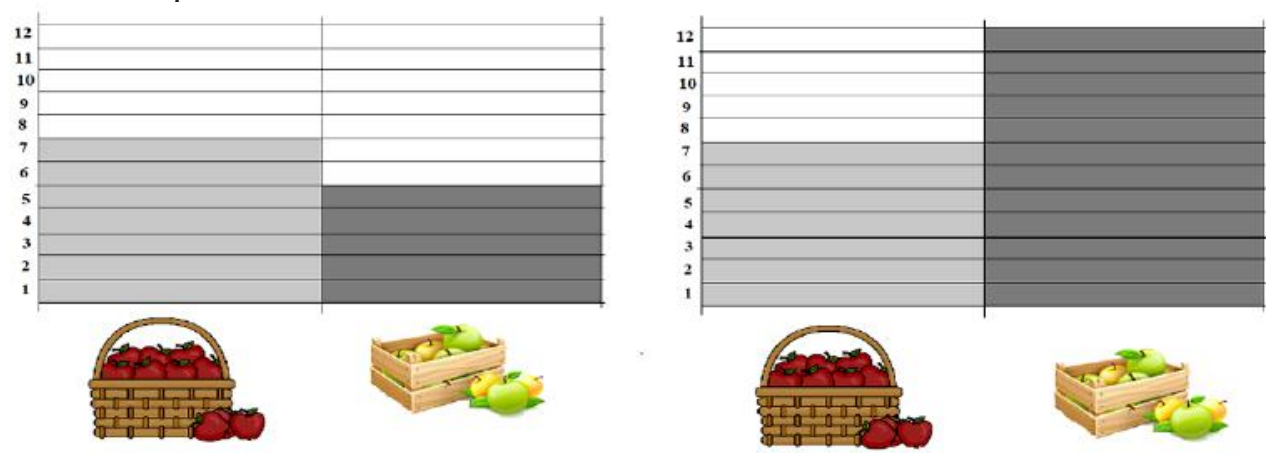

5. Измери отсечките и запиши техните дължини. Намери сбора им.
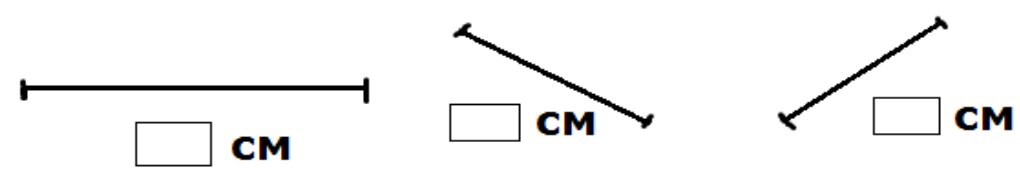

6. Часовникът показва часа, в който майката на Мила тръгва за работа. След 8 часа тя се прибира у дома. Нарисувай на другия часовник часа, в който се прибира майката на Мила.

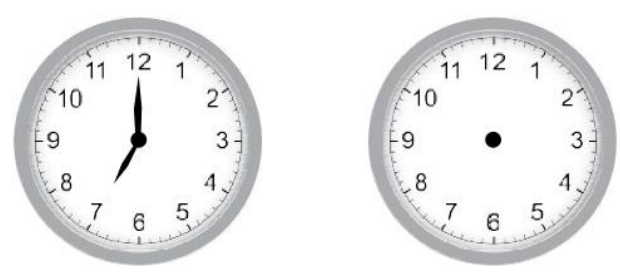




\section{БЕЛЕЖКИ}

1. Денев Д. Формиране на понятията в учебния процес, С., 1977 г., стр. 101.

\section{ЛИТЕРАТУРА}

БИЖКОВ, Г., 1995. Методология и методи на педагогическите изследвания. София: Аскони-Издат.

ДЕНЕВ, Д., 1977. Формиране на понятия в учебния прочес. София: Народна просвета.

СКАТКИН, М., 1965. Активизация познавательной деятельности учашихся в обучений. Москва: Просвещение.

СТАМЕНОВА, И., 2018. Развитие на четивната грамотност на учениците чрез проектна учебна дейност. София: Образование и познание.

СТОИМЕНОВА, Я., 2010. Индивидуалната помощ по математика на деца със социилнопедагогически проблеми. Благоевград: Неофит Рилски.

СТОИМЕНОВА, Я., 2005. Организация на творческата дейност на учениците в началните класове. Благоевград: Неофит Рилски.

СТОИМЕНОВА, Я., 2007. Урокът по математика в I-IV клас. Основни учебни дейности. Благоевград: Неофит Рилски.

\section{REFERENCES}

BIZHKOV, G., 1995. Metodologia I metodi na pedagogicheskite izsledvania. Sofia: Asconi-Izdat.

DENEV, D., 1977. Formirane na poncatia v uchebniq process. Sofia: Narodna Prosveta.

SKATKIN, M., 1965. Aktivizacia poznavatelnoj deqtelnosti uchashihsa v obuchenie. Moskva: Prosveshtenie.

STAMENOVA, I., 2018. Razvitie na chetivnata gramotnost na uchenicite chrez proektna uchebna deinost. Sofia: Obrazovanie I poznanie.

STOIMENOVA, Y., 2010. Individualnata pomosht po matematika na deca sus socialnopedagogicheski problemi. Blagoevgrad: Neofit Rilski.

STOIMENOVA, Y., 2005. Organizaciq na tvorcheskata deinost na uchenicite v nachalnite klasove. Blagoevgrad: Neofit Rilski.

STOIMENOVA, Y., 2007. Urokyt po matematika v I-IV klas. Osnovni uchebni deinosti. Blagoevgrad: Neofit Rilski. 


\title{
INCREASING THE LEVEL OF MATHEMATICAL KNOWLEDGE OF FIRST GRADE STUDENTS THROUGH WORKING WITH COLLECTED DATA BY HIMSELF
}

\begin{abstract}
Over the last decade, in terms of the learning process, methodologists and educators have been actively looking for a variety of means to motivate students' cognitive activity. This is related to the development and application in teaching practice of new approaches and didactic systems. This article examines the possibility of increasing the level of acquisition of mathematical knowledge by first grade students by applying the technique of "independent data collection" in the learning process. The knowledge of first grade students who have mastered the curriculum in mathematics with the help of independent research is diagnosed, establishing the effect of this activity on the level of mathematical knowledge.

Keywords: data handling; self-learning; raising the level of mathematical knowledge
\end{abstract}

Dr. Valentina Chileva, Assist. Prof. ORCID ID: 0000-0003-4413-5778

Department of Pre-School and Primary School Pedagogy

Faculty of Pedagogy

South-West University "Neofit Rilski"

Blagoevgrad, Bulgaria

E-mail: valentinach@swu.bg 